\title{
Southern elephant seal movements and Antarctic sea ice
}

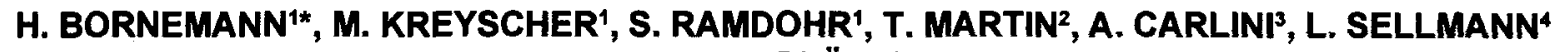 \\ and J. PLÖTZ' \\ 'Alfred-Wegener-Institut für Polar- und Meeresforschung, Postfach 1201 61, D-27515 Bremerhaven, Germany \\ ${ }^{2}$ Institut fiur Meereskunde, Düsternbrooker Weg 20, D-24105 Kiel, Germany \\ ${ }^{3}$ Departamento de Ciencias Biológicas, Instituto Antártico Argentino, Cerrito 1248, 1010 Buenos Aires, Argentina \\ ${ }^{4}$ Dienstleistung fü Wissenschaft und Forschung, Am Bremerhavener Innovations- und Gründerzentrum, Stresemannstrasse 46, \\ D.27568 Bremerhaven, Germany \\ *hbornemann@awi-bremerhaven.de
}

\begin{abstract}
Weaned pups and post-moult female elephant seals (Mirounga leonina) were fitted with satellite transmitters at King George Island (South Shetland Islands) between December 1996 and February 1997. Of the nine adult females tracked for more than two months, three stayed in a localized area between the South Shetland Islands and the South Orkney Islands. The other six females travelled south-west along the coast of the Antarctic Peninsula up to the Bellingshausen Sea. Two of them then moved north-east and hauled out on South Georgia in October. One female was last located north of the South Shetland Islands in March 1998. In total, eight females were again sighted on King George Island and six of the transmitters removed. The tracks of the weaners contrasted with those of the adults. In January, five juveniles left King George Island for the Pacific sector spending about four weeks in the open sea west of the De Gerlache Seamounts. Three of them returned to the tip of the Antarctic Peninsula in June, of which one was last located on the Patagonian Shelf in November 1997. The juveniles avoided sea ice while the adults did not. The latter displayed behavioural differences in using the pack ice habitat during winter. Some females adjusted their movement patterns to the pulsating sea ice fringe in distant foraging areas while others ranged in closed pack ice of up to $100 \%$. The feeding grounds of adult female elephant seals are more closely associated with the pack ice zone than previously assumed. The significance of the midwater fish Pleuragramma antarcticum as a potential food resource is discussed.
\end{abstract}

Received 4 May 1999, accepted 24 September 1999

Key words: foraging, juvenile, migration, movements, sea ice, southern elephant seal, telemetry

\section{Introduction}

Southern elephant seals (Mirounga leonina L.) have a circumpolar distribution and are mainly found on islands around the Antarctic Convergence. Their broad breeding range from Peninsula Valdes, Patagonia, to King George Island covers $c .20^{\circ}$ latitude. The large populations, wide distribution and high energy demands of elephant seals play an important role in the dynamics of their marine food resources, mainly squid and fish. There is thus growing interest in using systems such as satellite telemetry to identify the feeding grounds of different breeding populations of this top predator. Studies on the migratory behaviour of the southern elephant seal have been the subject of a number of publications. Most of that research was carried out on adult animals from the three large breeding stocks centred on South Georgia (e.g. Boyd \& Arnbom 1991, McConnell et al. 1992, McConnell \& Fedak 1996), Kerguelen (e.g. Bester \& Pansegrouw 1992, Slip 1997, Jonker \& Bester 1998) and Macquarie Island (e.g. Hindell et al. 1991a, 1991b, Slip et al. 1994). The studies showed that some elephant seals frequented the Antarctic polar front and on several occasions elephant seals have been sighted within the pack ice of the Southern Ocean (e.g. Laws 1960, King
1983, Laws 1984, Burton 1985, Gales \& Burton 1989). As pointed out by McConnell \& Fedak (1996), information on the foraging ranges and movements of elephant seals from different colonies may provide clues as to why some colonies are growing while others are declining, and will identify which areas of ocean are most important to this species.

Apart from some records of elephant seal births in localities beyond their principal breeding range, e.g. on Peterson Island at $66^{\circ} 27^{\prime} \mathrm{S}-110^{\circ} 30^{\prime} \mathrm{E}$ (Murray 1981), Stranger Point on King George Island represents the southernmost breeding colony of this species in the Antarctic. Every year between September and October about 600 females haul out at Stranger Point for parturition and weaners remain ashore for a further five to eight weeks during which they complete their moult. Recent research at that colony (Burton et al. 1997, Carlini et al. 1997, 1999) reports that females coming ashore to breed are heavier than those from other colonies, wean heavier pups and gain more mass between lactation and moult during less time at sea. Nothing is known about the foraging ranges and winter habitat of seals from this southernmost breeding site. In the present study, our objective was to partially fill that gap by tracking adult females and weaned pups using satellite telemetry, and 
characterising their seasonal pattern of movement relative to the pack ice distribution.

\section{Materials and methods}

The field work on southern elephant seals was carried out at Stranger Point on King George Island $\left(62^{\circ} 14\right.$ 'S $\left.-58^{\circ} 40^{\prime} \mathrm{W}\right)$ (Fig. 1) between December 1996 and February 1997.

\section{Satellite-linked dive recorders and data processing}

Seven two-month old juveniles (four males, three females born in October 1996) and 13 adult females were fitted with satellite transmitters after they had completed their moult (Table I). Two types of ARGOS (CLS/Service Argos, Toulouse, France) transmitters were used in this study: 1) Satellite transmitters (ST-10 Telonics, Mesa, AZ, USA) which were designed to provide the seals' at-sea locations, and 2) satellite-linked dive recorders(SDR T-6 Wildlife Computers, Redmond, WA, USA) which provided processed data on the locations and diving behaviour in the form of six hourly histograms transmitted to a polar-orbiting satellite. The data provide both the horizontal extent of the seals' movements and the vertical distribution of their dive depths. A comprehensive analysis of the dive records will be presented in a separate paper. The SDR had a seawater conductivity sensor to indicate the seal's extended at-surface time or
Table I. Data on transmitter deployment, departure, last transmission, duration of tracks, and haul out sites of seven juvenile and 13 adult female southern elephant seals fitted with satellite transmitters on King George Island.

Seal Date of Date of Date of last Tracking Haulout deployment departure transmission duration [d]

\begin{tabular}{lcccrl}
\hline Jm1 & 01.12 .96 & $?$ & 10.12 .96 & 9 & \\
Jf2 & 01.12 .96 & $?$ & 12.12 .96 & 11 & \\
Jm3 & 06.12 .96 & 30.12 .96 & 03.07 .97 & 209 & Livingston Island \\
Jm4 & 10.12 .96 & 31.12 .96 & 06.02 .97 & 58 & \\
Jf5 & 10.12 .96 & 31.12 .96 & 21.02 .97 & 73 & \\
Jf6 & 15.12 .96 & 05.01 .97 & 03.11 .97 & 323 & Elephant Island \\
Jm7 & 17.12 .96 & 03.01 .97 & 29.06 .97 & 194 & Livingston Island \\
Af1 & 17.01 .97 & 07.02 .97 & 01.08 .97 & 196 & King George Island $^{1}$ \\
Af2 & 18.01 .97 & 20.01 .97 & 17.10 .97 & 272 & King George Island $^{3}$ \\
Af3 & 22.01 .97 & 01.02 .97 & 10.02 .97 & 19 & \\
Af4 & 24.01 .97 & 28.01 .97 & 30.01 .97 & 6 & \\
Af5 & 25.01 .97 & 02.02 .97 & 14.03 .98 & 413 & South Georgia \\
Af6 & 09.02 .97 & 11.02 .97 & 12.04 .97 & 62 & \\
Af7 & 04.02 .97 & 06.02 .97 & 30.05 .97 & 115 & King George Island $^{1}$ \\
Af8 & 09.02 .97 & 18.02 .97 & 10.02 .98 & 366 & Livingston Island $^{1}$ \\
& & & & & King George Island $^{2}$ \\
Af9 & 10.02 .97 & 20.02 .97 & 28.05 .97 & 107 & King George Island $^{3}$ \\
Af10 & 12.02 .97 & 17.02 .97 & 23.02 .97 & 11 & \\
Af11 & 14.02 .97 & 22.02 .97 & 09.02 .98 & 360 & South Georgia ${ }^{1}$ \\
& & & & & King George Island $^{2}$ \\
Af12 & 15.02 .97 & 16.02 .97 & 28.04 .97 & 72 & \\
Af13 & 18.02 .97 & 27.02 .97 & 10.03 .97 & 20 & \\
\hline
\end{tabular}

('Breeding, ${ }^{2}$ Moulting)

$\mathbf{J}=$ juvenile, $A=$ adult,$f=$ female,$m=$ male .

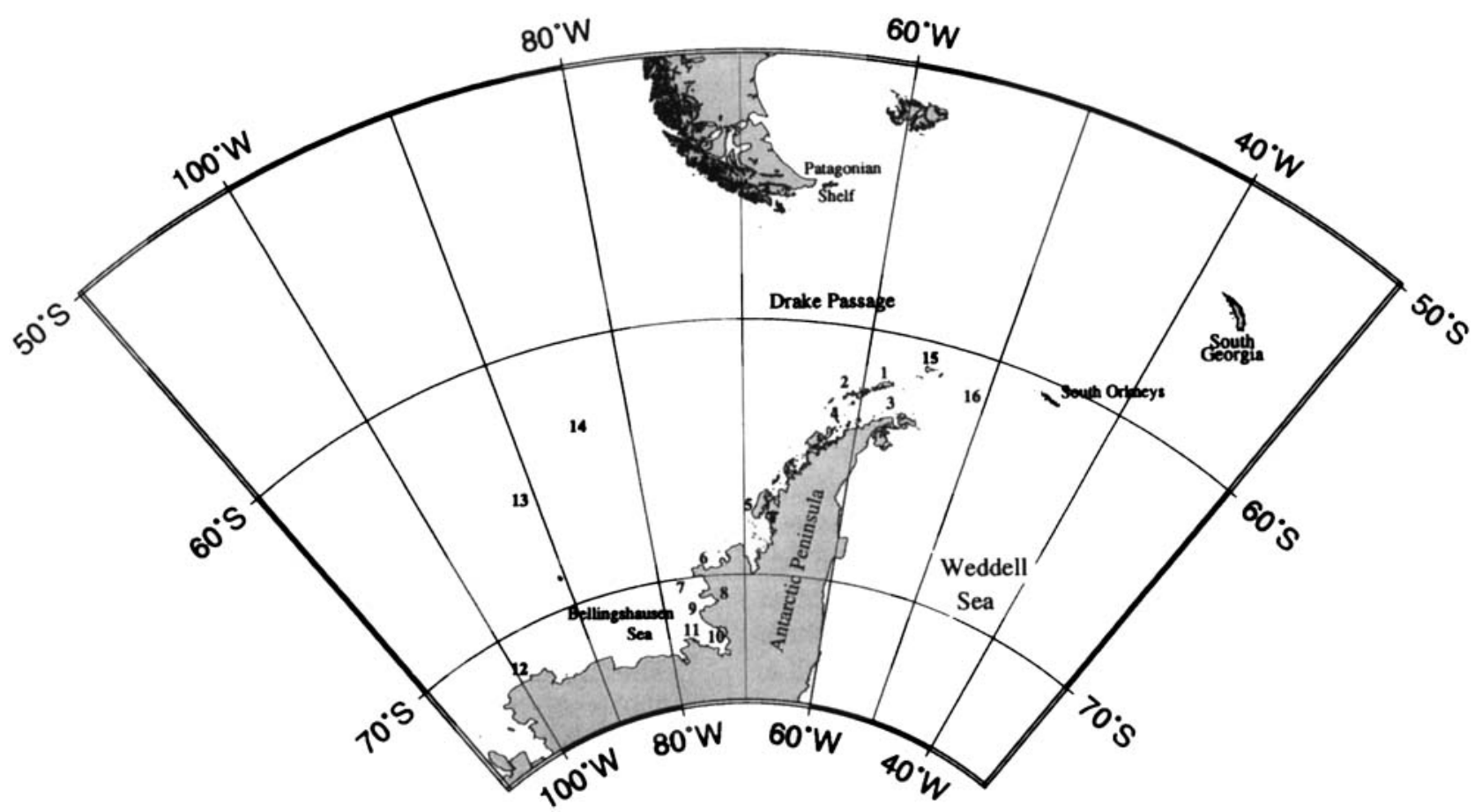

Fig. 1. The region of the Antarctic Peninsula and adjacent areas showing the location of all place names used in text. 1. King George Island*, 2. Livingston Island*, 3. Bransfield Strait, 4. Brabant Island, 5. Adelaide Island, 6. Rothschild Island, 7. Latady Island, 8. Alexander Island, 9. Beethoven Peninsula, 10. Ronne Entrance, 11. Smyley Island, 12. Thurtson Island, 13. De Gerlache Seamounts, 14. Bellingshausen Abyssal Plain, 15. Elephant Island, 16. Scotia Arc, *South Shetland Islands. 
haulout on land or ice. Messages were transmitted at $90 \mathrm{~s}$ intervals when the sensor was disconnected for at least three consecutive transmission intervals of $50 \mathrm{~s}$. For the analyses the percentage of $90 \mathrm{~s}$ transmissions per day was used. Eight of the 15 SDRs used additionally provided the surface or hauled-out information at higher resolution. These "timeline messages" covered a 24 -hour period divided into 72 twentyminute increments. The SDR used readings from the conductivity sensor at $10 \mathrm{~s}$ intervals for each $20 \mathrm{~min}$ period and reported whether the majority of the readings during that period were "wet" or "dry". Timelines for the previous four days were transmitted. See Priede \& French (1991), Bengtson (1993) and Bengtson et al. (1993) for further details on SDR technology.

The transmitters were fixed to a star-shaped gauze mat glued to the fur on animals' backs (two juveniles SDR T-6) or heads (five juveniles Telonics ST-10; 13 adults SDR T-6) using a quick-setting epoxy resin. Incoming ARGOS data were decoded by using the program "SatPack" (Wildlife Computers). Location data coded as class A, B, 0, 1, 2, and 3 were filtered using the algorithm of McConnell et al. (1992) allowing a maximum speed of $3.5 \mathrm{~m} \mathrm{sc}^{-1}$. No corrections were made where locations overlaid coastlines. Location data to be used for the computer animation (see below) were interpolated linearly based on the cycle of the histogram periods. All statistical procedures used computer program SigmaStat 2.0 (SPSS Science Software GmbH).

\section{Satellite-derived data on sea ice concentration}

Polar-orbiting satellites may provide large-scale characterization of the Antarctic sea ice cover. Since 1987 the Special Sensor Microwave/Imager (SSM/I) as part of the Defence Meteorological Satellite Program (DMSP) has recorded the all weather day and night passive microwave brightness temperature. Daily mean ice concentrations were retrieved by the NASA-Team-Algorithm (Cavalieri et al. 1984) from $0 \%$ (open water) to $100 \%$ (closed ice cover) on a polar stereographic grid with a spatial resolution of $25 \mathrm{~km}$. The absolute errors found by Comiso et al. (1997) are about 10$20 \%$ in the Antarctic region. For the present study the corresponding ice concentrations were interpolated to the observed locations of elephant seals.

Computer animation was developed to visualize the animals movements in relation to the extent and concentration of sea ice. The QuickTime (Apple Computer, Inc.) animation is published in the homepage of the Alfred Wegener Institute for Polar and Marine Research.

\section{http://www.awi-bremerhaven.de/ecology/ SealAnimation/seal_animation-e.html}

A two-monthly series of images derived from the animation between December 1996 and February 1998 is given in Fig. 2. The images show the region of the Antarctic Peninsula. Juvenile elephant seals are represented by a yellow symbol, adults by a green one. See Table I for data on transmitter deployment, departure, last transmissions, duration of tracks, and haul out sites.

\section{Immobilization}

A combination of ketamine, xylazine, and diazepam was used to immobilize the seals prior to the attachment of the transmitters. The initial doses of the drugs were either administered by hand (juveniles) or by using a dart gun (adults) with automatically evacuating syringes (Telinject, Römerberg, Germany). All injections were given intramuscularly into the gluteal region. The initial doses were calculated after conservatively estimating the body weight. Juveniles were drugged with ketamine and diazepam in doses of $500 \mathrm{mg}$ ketamine plus $10 \mathrm{mg}$ diazepam per seal. Maintenance of narcosis was achieved by small follow-up doses of 100$200 \mathrm{mg}$ ketamine and 5-10 $\mathrm{mg}$ diazepam respectively. For the immobilization of the adult females a $20 \mathrm{ml}$ dart-syringe was filled with $14-16 \mathrm{ml}$ ketamine $\left(100 \mathrm{mg} \mathrm{ml}^{-1}\right)$ plus $1-2 \mathrm{ml}$ xylazine (125 mg xylazine dissolved in $100 \mathrm{mg}$ ketamine $\mathrm{ml}^{-1}$ ). Initial doses ranged between 1600-2000 mg ketamine with 125-250 mg xylazine per seal. Maintenance of immobilization during fixing of the SDRs was achieved by up to eight follow-up doses of 50-1000 mg ketamine, which were occasionally complemented by $0.6-125 \mathrm{mg}$ xylazine per animal. Those injections were administered by hand.

\section{Results}

Of the 20 satellite transmitters used during this study, three failed within the first, three in the second and four in the third month of deployment. Of the remaining ten devices, four operated for as long as 12,13,13 and 15 months (Table I). A total of 7356 location fixes were obtained. Table II gives the proportion of location classes A, B, $0,1,2$, and 3 (ARGOS 1996). The loss of locations after filtering the data amounted to $22.9 \%$ (A), $34.2 \%$ (B), $25.8 \%$ (0), $13.3 \%$ (1). $14.3 \%$ (2), and $12.2 \%(3)$.

Table II. Total number of locations of seven juvenile and 13adult female elephant seals before and after filtering the location data (algorithm by McConnell et al. 1992). The seals were fitted with satellite transmitters on King George Island between December 96 and February 97.

\begin{tabular}{lcccccc}
\hline Location class & $\mathrm{A}$ & $\mathrm{B}$ & 0 & 1 & 2 & 3 \\
\hline Loc. before filtering & 1735 & 3040 & 1216 & $\mathbf{8 4 1}$ & 385 & 139 \\
Daily location rates & $\mathbf{0 . 6 6 2}$ & $\mathbf{1 . 4 7 8}$ & 0.523 & 0.467 & 0.227 & 0.075 \\
Loc. after filtering & 1338 & 2001 & 902 & 729 & 307 & 122 \\
Daily location rates & 0.484 & 0.880 & 0.438 & 0.524 & 0.221 & 0.076 \\
\hline
\end{tabular}

Location classes (ARGOS 1996), and accuracy of locations given as deviation from the true location: $A, B=$ no estimate of location accuracy (only since 8 February 1997); $0=$ above $1000 \mathrm{~m} ; 1=$ between 350 and $1000 \mathrm{~m} ; 2=$ between 150 and $350 \mathrm{~m} ; 3=$ less than $150 \mathrm{~m}$. 

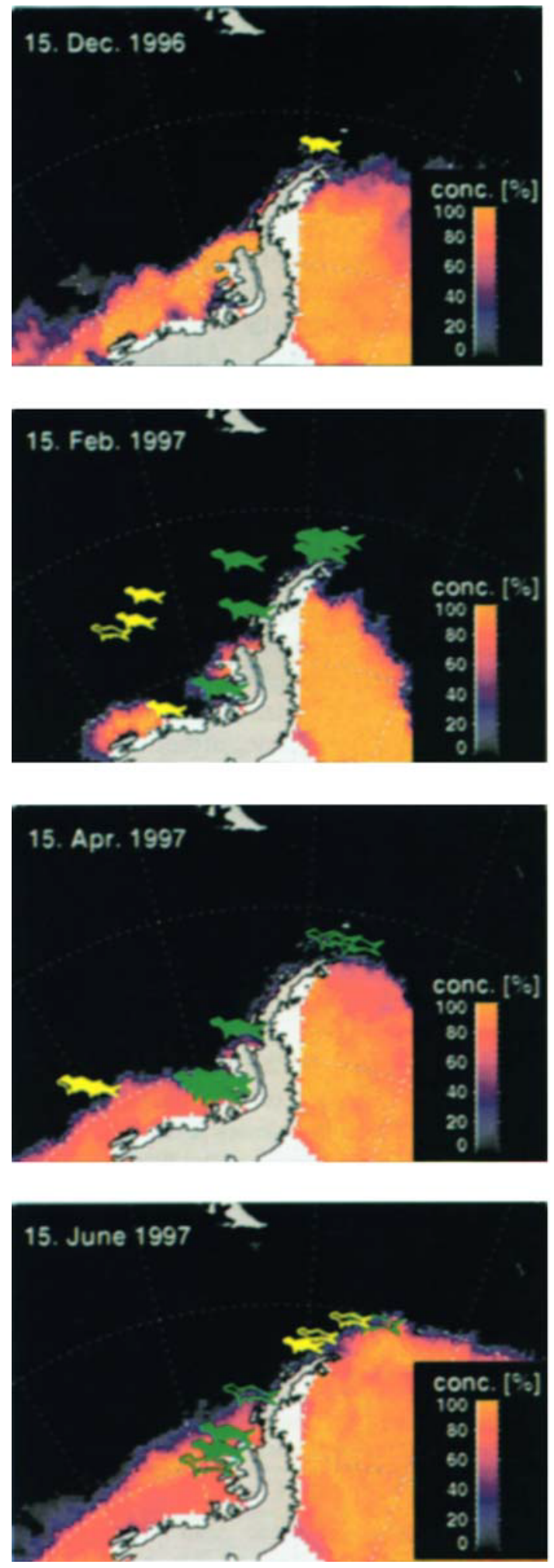
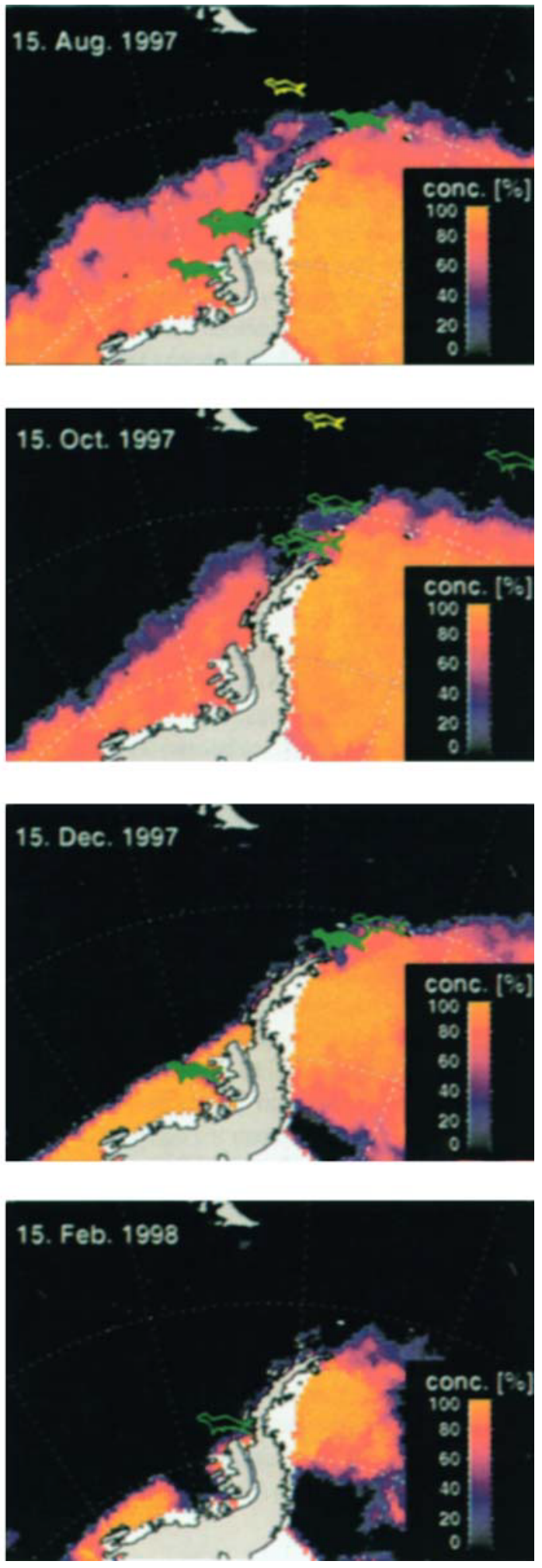

Fig. 2. Two-monthly series of images of the pack ice distribution and concentration in the region of the Antarctic Peninsula between December 1996 and February 1998. The images are derived from SSM/I ice concentration data visualized in a computer animation, which is incorporated in the homepage of the Alfred Wegener Institute for Polar and Marine Research; see text. The images show the Antarctic Peninsula (land mask: grey; ice shelf: white, sea ice: colour coded). Juvenile elephant seals are represented by a yellow and adults by a green symbol. Interpolated locations are marked: if an animal was lost to the satellite for longer than 24 hours the seal symbol appears as an outline. If subsequently picked up again by the satellite then full colour returns to the symbol. 


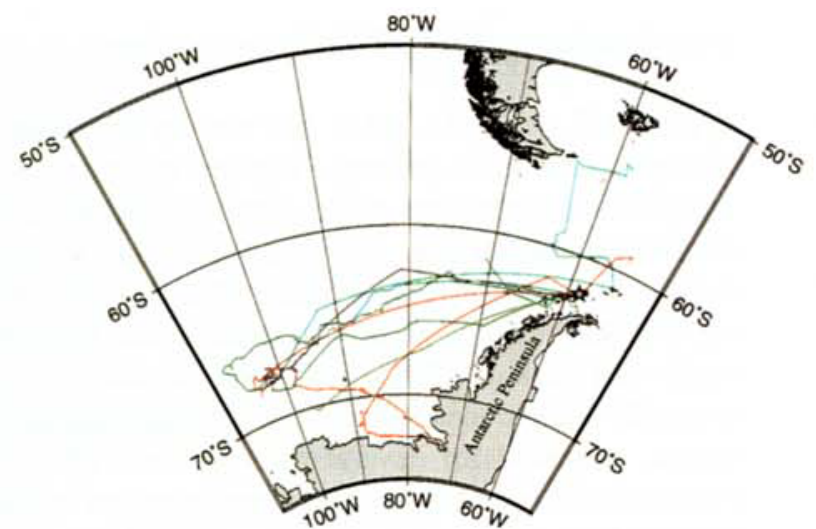

\begin{tabular}{|l|}
\hline Jm3 \\
Jm4 \\
Jf5 \\
Jf6 \\
Jm7 \\
King George Island \\
\hline
\end{tabular}
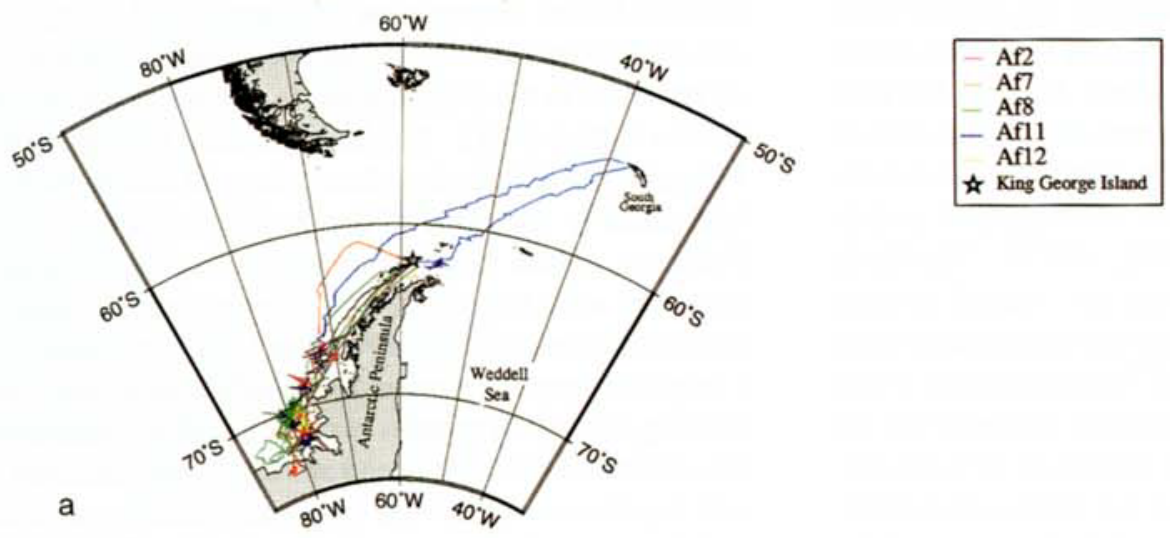

- Af5

4. King George Island
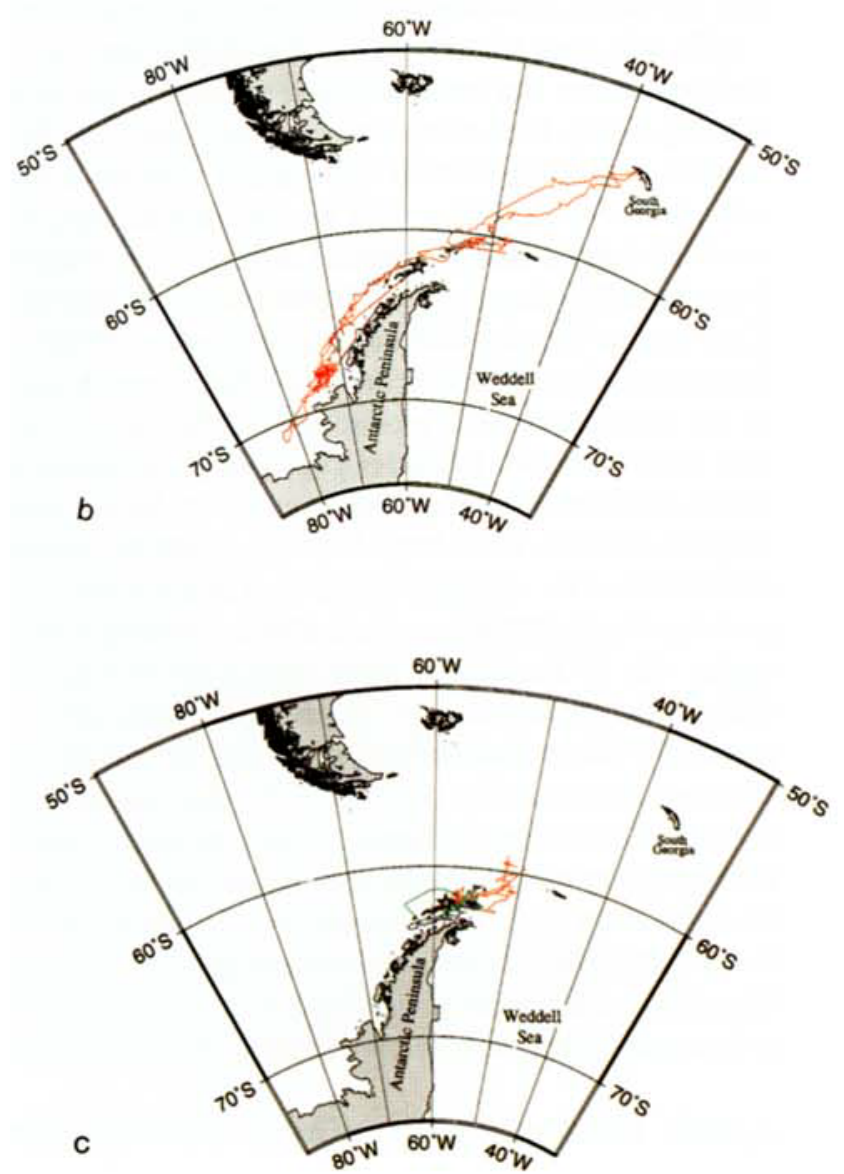

Fig. 3. Tracks of five satellitetagged juvenile southern elephant seals. The seals left King George Island in December 1996.
Fig. 4. Tracks of nine satellitetagged adult female southern elephant seals. The seals left King George Island in January/ February 1997. The seals were classified as $a_{\text {. }} A_{1}$ : large-scale tracks close to substantial ice concentrations, b. $A_{2}$ : largescale tracks close to the ice margin, c. $A_{3}$ : small-scale tracks close to the ice margin. 


\section{Movements of juvenile elephant seals}

The satellite transmitters of two juvenile elephant seals failed within the first month of deployment. The tracks of the remaining five tagged juveniles are shown in Fig. 3. The acronyms (see below) denote the individual seals (Table I).

All juveniles stayed near King George Island until end of December 1996. At that time the pack ice had retreated leaving only small fields of ice concentrations of up to $35 \%$ around the South Shetland Islands. Seals Jm3, Jf5 and Jm7 migrated westward along $62^{\circ} \mathrm{S}$, until $\mathrm{Jm} 7$ detached on 29 January and headed due south. Jm4 and Jf6 passed the Bransfield Strait and followed the others in the second week of January. Jf6 had caught up with Jm 3 and Jf5 by the end of January while $\mathrm{Jm} 4$ followed $\mathrm{Jm} 7$. Jm3, Jf5 and Jf6 then travelled in south-westerly direction and Jf5 was the first to reach the ice-free waters over the De Gerlache Seamounts $\left(65^{\circ} \mathrm{S}-92^{\circ} \mathrm{W}\right)$ in mid February before transmissions ended. $\mathrm{Jm} 3$ and Jf6 continued to around $67^{\circ} \mathrm{S}, 108^{\circ} \mathrm{W}$. The fairly consistent migratory paths of $\mathrm{Jm} 4$ and $\mathrm{Jm} 7$ varied in early February. $\mathrm{Jm} 4$ was located for two days at the northern edge of a residual ice field about $400 \mathrm{~km}$ off Thurston Island. From there it moved in north-westerly direction towards the De Gerlache Seamounts; transmissions ended on 6 February. $\mathrm{Jm} 7$ came into contact with the same ice field a week later, travelled along its outer edge eastward to the coast of the Bellingshausen Sea and reached the inner parts of the almost ice-free Ronne Entrance on 26 February. After leaving that area, $\operatorname{Jm} 7$ migrated far to the north-west and joined $\operatorname{Jm} 3$ and $\mathrm{Jf6}$ in mid March over the Bellingshausen Abyssal Plain. The prolonged travel period of the three juveniles was interrupted for about one month by a more stationary phase in the ice-free ocean west of the De Gerlache Seamounts, almost a $1700 \mathrm{~km}$ straight-line distance from their natal site. During April, and in time with the northward extension of the ice edge, Jm3, Jf6 and $\operatorname{Jm} 7$ headed back north-east. In June, following roughly their previous route, they reached the South Shetland Islands, hauled out for some days and then dispersed further northward. They remained there until early July at which point the transmitters of $\mathrm{Jm} 3$ and $\mathrm{Jm} 7$ failed. At the beginning of August the pack ice edge extended to $60^{\circ} \mathrm{S}$ and Jf6 came into contact with the ice again. The animal then traversed the Drake Passage, reached the Patagonian Shelf in early September and was last located in November 1997.

\section{Movements of adult female elephant seals}

The movements of the nine adult females (Fig. 4) were classified according to travel distances and association with different ice concentrations: $\left(A_{1}\right)$ large-scale tracks close to substantial ice concentrations, $\left(A_{2}\right)$ large-scale tracks close to the ice margin, and $\left(\mathrm{A}_{3}\right)$ small-scale tracks close to the ice margin. The acronyms (see below) denote the individual females presented in Table I. The transmission periods of Af 3 , Af4, Af10, and Af1 3 lasted for a maximum of two months and were therefore excluded from further analyses.

$A_{1}(A f 2, A f 7, A f 8, A f 11, A f 12)$ : Af2 was the first to leave King George Island on 20 January. The seal moved to the southwest following the coast of the Antarctic Peninsula towards the Bellingshausen Sea. From early February to late March the sea ice decreased to a minimum. The first ice contact was on 30 January at the coast of Alexander Island. From there the southward track of Af2 slowed while the animal crossed an area of $80 \%$ ice concentration. On 6 February it passed Latady Island, remained for several days in front of Beethoven Peninsula and reached its southernmost position inside the ice covered Ronne Entrance on 24 March. Af7, Af8, Afl 1 and Af 12 left their moulting site between 6 and 22 February. They all travelled to the Bellingshausen Sea on a path remarkably similar to that of Af2. Af7, as it left King George Island on 5 February, made a detour to the north-west but moved five days later back to the coast of the Antarctic Peninsula. On 21 February, it had first ice contact at Alexander Island and remained until the end of March near Smyley Island in ice concentrations of $c .60 \%$. From there, Af7 continued to follow a migratory pattern similar to that of the four other females, moving for several months back and forth in a localized shelf area west of Alexander Island and the Ronne Entrance. From mid April onwards the sea ice extent steadily increased and within two weeks the entire Bellingshausen Sea was covered by concentrations of up to $100 \%$. The transmitters of Af12 and Af7 failed at the end of April and May, respectively.

Af2, Af8, and Af1 1 stayed in the interior pack ice of the Bellingshausen Sea until mid June ranging as far as $90^{\circ} \mathrm{W}$. Moving slowly back north through heavy pack ice, the three females synchronized their movements with the northward extension of the ice edge. Af2 was the first to reach the area west of Adelaide Island at the end of June. In mid September it continued heading north and hauled out on 29 September at King George Island where transmissions ended 19 days later. During that time the South Shetland Islands were surrounded by ice concentrations of around $40 \%$. Af 8 reached the same area in mid October, hauled out on Livingston Island for one month apparently to breed, and then moved back southward. On 24 November, it reached Alexander Island the second time and remained for about six weeks west of the island in closed pack ice of up to $90 \%$ concentration before heading northwards again. On 18 January, it again hauled out at King George Island where transmissions ended three weeks later. Af1 1 passed the South Shetland Islands during the second week of October, left the sea ice zone on 16 October and travelled far north-east to the South Atlantic. It reached South Georgia via the Scotia Arc on 27 October and hauled out for 23 days. On the same route back, Af1 1 passed the Bransfield Strait again in early December, remained in the marginal ice zone close to King George Island for about five weeks and then hauled out at Stranger Point where transmissions ended on 10 February.

$A_{2}$ (Af5): This female left King George Island on 2 February 
and moved towards the Bellingshausen Sea. It passed Rothschild Island on 21 February, arrived at the coast of Latady Island the following day and stayed for five days in the marginal ice zone near Beethoven Peninsula where it had its most southerly position. On the slower return track, the seal arrived at the northern tip of Alexander Island on 10 March staying there for about seven weeks exclusively at the interface between ice and open water. At the beginning of May, the track continued slowly northward with the growing ice edge. The seal passed Adelaide Island on 12 June, and King George Island and Elephant Island within the first week of August before heading due east towards the area of the South Orkney Islands where it stayed until 20 September. The seal left the pack ice zone in early October and reached South Georgia on 10 October to haul out for 29 days. On the trip back, the seal never moved into the pack ice, although it followed the periphery of the pack closely in a westerly direction via the South Orkney Islands and Elephant Island up to the Bransfield Strait. It turned due south at the end of December travelling along the almost ice-free coast of the Antarctic Peninsula directly to the area between Adelaide and Alexander Island which it had left about nine months previously. In early March, about two months later, it turned back northward and transmissions ended on 14 March near Brabant Island.

$A_{3}(A f 1, A f 6, A f 9)$ : The three females left their moulting site at Stranger Point between the second and third week of February and spent about one month in the almost ice-free waters around the South Shetland Islands. In mid April they travelled slowly eastward to the tip of the Antarctic Peninsula where they stayed within the northern fringe of a pack ice zone which, during that time, extended to the central parts of the

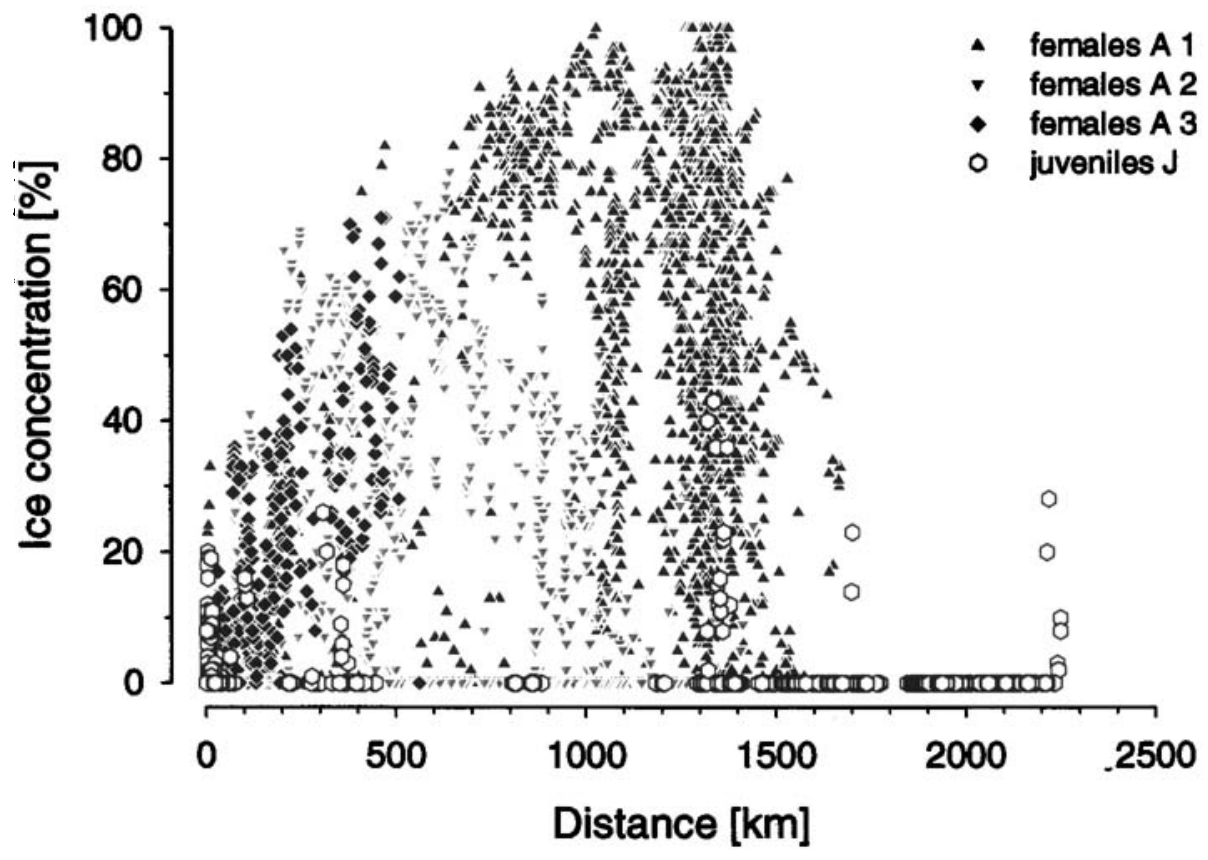

Weddell Sea. By the end of May, only the transmitter of female Afl was operating. In June the seal touched the marginal sea ice zone between the South Shetland Islands and South Orkney Islands. On 6 July it reached its most northerly position, about $600 \mathrm{~km}$ straight-line distance from King George Island. Transmission ended on 1 August.

In total, eight females were again localized at King George Island and six of the transmitters removed by an Argentinean field team after the females came ashore to give birth between October and November 1997. These were females Af1, Af2, Af3, Af4, Af7 and Af9. Except for the unit of Af2, all failed during the period at sea.

\section{Association with sea ice}

The complex information obtained from the varying movements of the five juvenile and nine adult female elephant seals in conjunction with daily SSM/I-data on sea ice concentration was analysed visually by running a computer animation. Two-monthly series of satellite imageries are presented in Fig. 2. Figure 5 gives the distribution of all seal locations $(n=5969)$ related to migratory distance against ice concentration. The clusters of the nine females $\left(A_{1}, A_{2}, A_{3}\right)$ and the five juveniles $(\mathrm{J})$ are clearly discernible although overlaps exist due to the fact that several seals migrated on similar routes for some time. The differences between the females classified as $A_{1}, A_{2}$, and $A_{3}$ and the juveniles are shown in the frequency distribution histograms of Fig. 6 . In addition the distances of seals at their locations to the nearest ice edge defined as $15 \%$ ice concentration was measured. We examined the four seal classes $\left(A_{1}, A_{2}, A_{3}, J\right)$ for differences between ice concentrations at seal positions, straight-line
Fig. 5. The distance of all locations ( $n=5969)$ of nine adult female elephant seals, coded by the classification described in text as $A_{1}$ : (black triangles), $A_{2}$ : (grey triangles), $A_{3}$ : (black diamonds), and five juveniles (hollow hexagons). Interpolated locations are not included. 
Females $A_{1}$

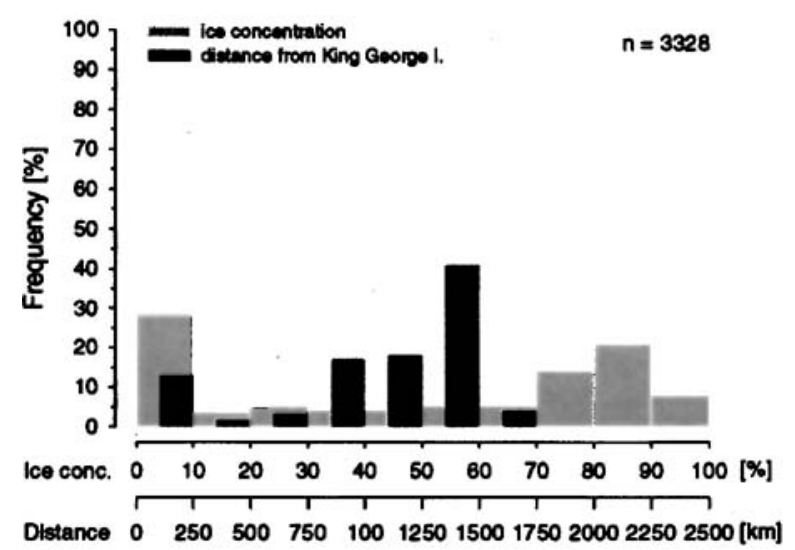

Females $\mathrm{A}_{3}$

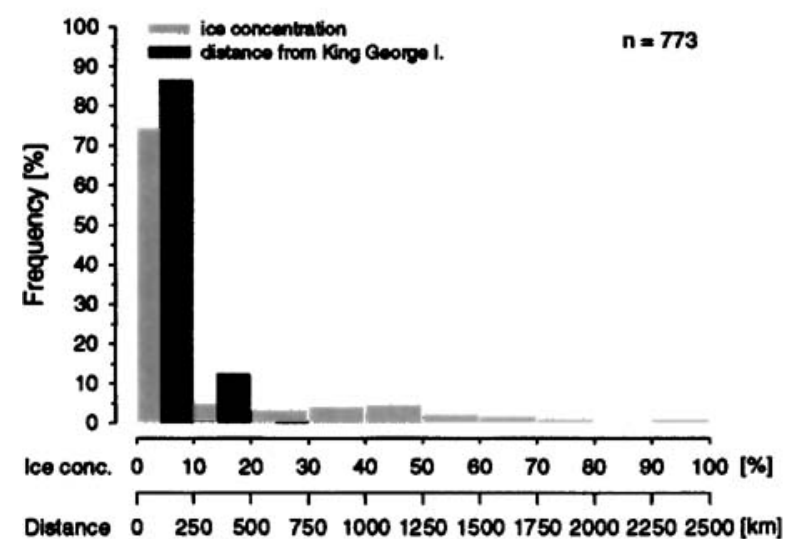

Females $A_{2}$

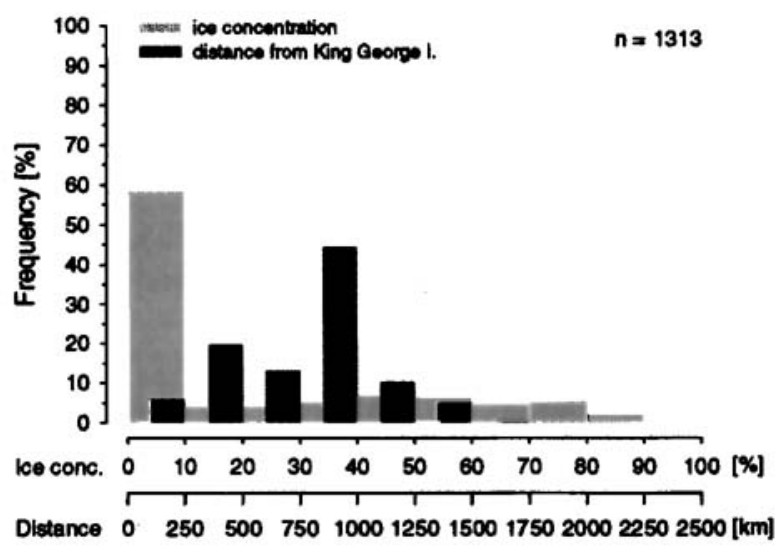

Juveniles J

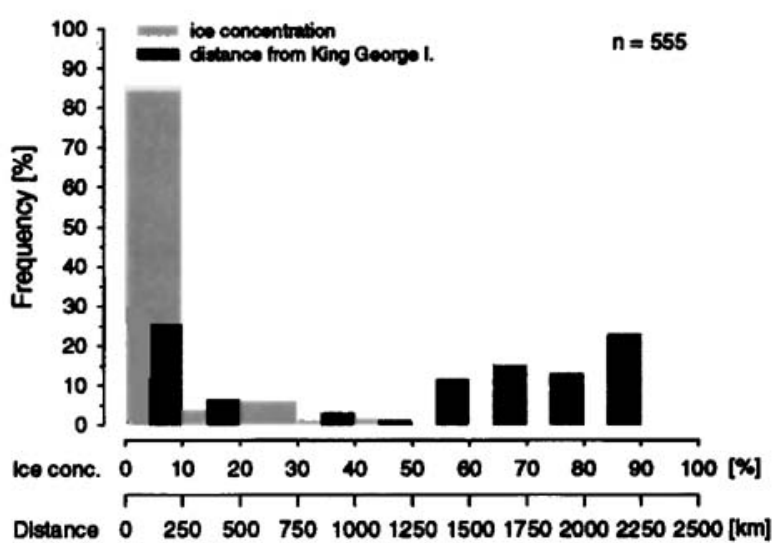

Fig. 6. Frequency distribution histograms of ice concentrations and distance values at seal positions calculated for nine adult female elephant seals classified (in text) as $A_{1}, A_{2}, A_{3}$, and five juveniles $J$.

distances to King George Island, distances to the nearest ice edge, daily migration distances within the tracks, and the amount of "dry-readings" of the SDRs' saltwater switch as an equivalent for the amount of at-surface time (Table III). The Kolmogorov-Smirnov test for normality failed for all parameters in the four classes of seals $(P<0.001)$. We therefore performed a rank transformation of the data and used a Kruskal-Wallis one-way analysis of variance (ANOVA) on ranks which showed significant differences between the four seal classes (defined as $H$-values: 2606.789 (ice concentration), 2388.237 (distance from King George Island), 2398.508 (distance from ice edge), 765.433 (daily distance), 1300.563 (dry readings), $P<0.001$ ). An all pairwise multiple comparison procedure was performed to compare the seal classes between each other. The advanced Tukey-Kramer comparison of rank means (Dunn's test, SigmaStat 2.0, SPSS Science Software) revealed significant differences for all parameters between all seal classes ("large $Q$-values", $P<$ 0.05 ).

\section{At-surface behaviour}

The at-surface behaviour of the seals was examined to test the hypothesis that the duration of time spent at the sea surface or on the ice was influenced by the ice concentration. The low resolution data based on the different transmission rates $(90 \mathrm{~s}$ "on land", $50 \mathrm{~s}$ "at sea") were examined to see whether they were correlated with the high resolution timeline data. Only eight of the 15 SDRs had this option, and five of them provided adequate data. As these five units did not correspond to the defined seal classes $\left(A_{1}, A_{2}, A_{3}, J\right)$, this correlation had to be made at the individual level. Af2, Af6, Af8, Af9, and Af1 1 were examined after rank transformation of the data by using a Spearman rank order correlation. All five seals showed significant $(P<0.05)$ correlation between dry-readings and timelines with positive correlation coefficients between 0.481 and 1 . Statistically significant, but weak, correlation $(P<$ 0.05 , Spearman rank order correlation) between ice concentration values and dry-readings were found for seal classes $\mathrm{A}_{1}$ and $\mathrm{J}$ with a negative correlation coefficient $\left(r_{s}=\right.$ $-0.0983)$ for $A_{1}$ and a positive correlation coefficient $\left(r_{s}=\right.$ 
Table III. Descriptive statistics of ice concentrations, distances from King George Island, distances from ice edge, daily distances, and "dryreadings" at seal locations for nine adult female elephant seals classified (in text) as $A_{1}, A_{2}, A_{3}$, and five juveniles $J$.

\begin{tabular}{|c|c|c|c|c|}
\hline Parameter & $A_{1}$ & $\mathrm{~A}_{2}$ & $\mathrm{~A}_{3}$ & $\mathrm{~J}$ \\
\hline \multicolumn{5}{|c|}{ Ice concentration [\%] } \\
\hline Sample size & 3328 & 1313 & 773 & 555 \\
\hline 25. Percentile & 5.0 & 0.0 & 0.0 & 0.0 \\
\hline Median & 56.0 & 0.0 & 0.0 & 0.0 \\
\hline Mean & 48.1 & 16.1 & 8.3 & 2.1 \\
\hline 75. Percentile & 82.0 & 34.0 & 8.0 & 0.0 \\
\hline \multicolumn{5}{|c|}{ Distance from King George Island $[\mathrm{km}]$} \\
\hline Sample size & 3328 & 1313 & 773 & 555 \\
\hline 25. Percentile & 837.0 & 495.0 & 66.0 & 134.5 \\
\hline Median & 1218.0 & 887.0 & 125.0 & 1535.0 \\
\hline Mean & 1024.1 & 767.2 & 144.5 & 1221.6 \\
\hline 75. Percentile & 1335.0 & 956.0 & 190.0 & 1973.8 \\
\hline \multicolumn{5}{|c|}{ Distance from ice edge $[\mathrm{km}]$} \\
\hline Sample size & 3323 & 1313 & 773 & 555 \\
\hline 25. Percentile & 63.0 & 43.0 & 33.0 & 44.0 \\
\hline Median & 129.0 & 73.0 & 66.0 & 160.0 \\
\hline Mean & 212.9 & 106.4 & 76.8 & 216.1 \\
\hline 75. Percentile & 335.5 & 118.8 & 104.0 & 315.0 \\
\hline \multicolumn{5}{|c|}{ Daily distance $[\mathrm{km}]$} \\
\hline Sample size & 1190 & 413 & 373 & 519 \\
\hline 25. Percentile & 14.2 & 17.2 & 10.3 & 9.6 \\
\hline Median & 32.6 & 41.8 & 23.8 & 23.8 \\
\hline Mean & 42.9 & 48.1 & 33.4 & 29.8 \\
\hline 75. Percentile & 63.1 & 70.4 & 45.4 & 47.1 \\
\hline \multicolumn{5}{|c|}{ "Dry readings" [\%] } \\
\hline Sample size & 826 & 315 & 207 & 153 \\
\hline 25. Percentile & 0.0 & 0.0 & 0.0 & 0.0 \\
\hline Median & 0.0 & 0.0 & 0.0 & 0.0 \\
\hline Mean & 7.2 & 6.8 & 16.9 & 10.5 \\
\hline 75. Percentile & 0.0 & 3.0 & 25.8 & 0.0 \\
\hline
\end{tabular}

0.332 ) for J. No significant correlation was found for the classes $A_{2}$ and $A_{3}$. Table IV shows the results in detail. To increase the power of the analysis of the at-surface behaviour a Spearman rank order correlation analyses was performed for the five females whose SDRs calculated timelines. Significant $(P<0.05)$, but weak, correlation between the amount of dryreadings measured in 20 -minute increments and ice concentration were found for Af8 and Af 11 with a negative for Af8 $\left(r_{s}=-0.286\right)$ and a positive correlation coefficient for Af1 $1\left(r_{s}=0.136\right)$. No significant $(P>0.05)$ correlations were found for Af2, Af6 and Af9.

Contiguous series of one or more "dry" 20 min timeline intervals were denoted as extended surface intervals (ESIs = surfacing $>10 \mathrm{~min}$ ). Timing and duration of the ESIs varied remarkably. They occurred at any time and for any length between $20 \mathrm{~min}$ (= smallest measuring interval) and $20 \mathrm{~h}$. They almost never occurred in ice-free areas and were rare when seals migrated straight between breeding/moulting areas and foraging grounds. Because the SDR suspended transmissions after 6 hour of consecutive "dry" transmissions, breeding and moulting periods appear as gaps inside the continuous data records. Directly before and after these gaps
Table IV. Results of the Spearman rank order correlation analyses of the at-surface behaviour.

\begin{tabular}{lccc}
\hline & \multicolumn{3}{c}{ dry-readings vs timelines } \\
Seal & $n$ & $r_{s}$ & $P$ \\
Af2 & 142 & 0.665 & $<0.00001$ \\
Af6 & 43 & 0.418 & 0.00544 \\
Af8 & 218 & 0.579 & $<0.00001$ \\
Af9 & 65 & 1.000 & $<0.00001$ \\
Af1 1 & 262 & 0.708 & $<0.00001$ \\
& & & \\
Group & $n$ & $r_{s}$ & $P$ \\
A1 & 826 & -0.0983 & 0.00468 \\
A2 & 315 & -0.0034 & 0.95200 \\
A3 & 207 & 0.0499 & 0.47500 \\
J & 153 & 0.3320 & $<0.00001$ \\
& & & \\
Seal & $n$ & timelines vs ice concentration \\
Af2 & 93 & -0.0995 & 0.3420 \\
Af6 & 34 & -0.2030 & 0.2470 \\
Af8 & 156 & -0.2860 & $<0.0001$ \\
Af9 & 41 & -0.1860 & 0.2430 \\
Af1 & 228 & 0.1360 & 0.0401 \\
\hline
\end{tabular}

For dry readings vs timelines and timelines vs ice concentrations: five adult female elephant seals; for dry-readings vs ice concentration: nine adult females classified (in text) as $\mathrm{A}_{1}, \mathrm{~A}_{2}, \mathrm{~A}_{3}$, and five juveniles $\mathrm{J} . r_{S}=$ correlation coefficient.

the timeline messages often revealed ESIs over complete days. This shore-related behaviour is assumed to belong to the breeding/moulting period and is excluded from further analyses (see Table V).

The percentage of time spent at the surface (measured by ESIs) was $4.05 \%$ (Af2), $5.90 \%$ (Af6), $1.44 \%$ (Af8), $2.89 \%$ (Af9), and $4.48 \%$ (Af1 1). ESIs tended to concentrate in irregular clusters on consecutive days and during certain times of the day. These periods of the day usually did not exceed roughly $12 \mathrm{~h}$. The clusters occurred irregularly over periods of several weeks. The general timing between clusters varied slightly by shifting to earlier hours during the course of the tracking period.

Table V. Details of extended surface intervals (ESIs) measured by timeline messages for five adult female elephant seals fitted with satellite transmitters on King George lsland between January and February 97.

\begin{tabular}{lccccc}
\hline & Af2 & Af6 & $\begin{array}{c}\text { Seal } \\
\text { Af8 }\end{array}$ & Af9 & Af1 1 \\
\hline Parameter & \multicolumn{1}{c}{ Af2 } & 62 & 366 & 107 & 360 \\
\hline Duration of tracks [d] & 272 & 18 & 160 & 50 & 103 \\
Days without data* & 120 & 13 & 20 & 16 & 135 \\
Number of ESIs & 37 & 13 & 0.097 & 0.281 & 0.525 \\
ESIs per day & 0.243 & 0.295 & & & \\
Duration of ESIs [min] & & & & 20 & 20 \\
25. Percentile & 20 & 20 & 20 & 20 & 40 \\
Median & 60 & 60 & 20 & 20 & 123 \\
Mean & 239 & 288 & 214 & 148 & 100 \\
75. Percentile & 460 & 100 & 430 & 160 & 16580 \\
Sum of ESIs [min] & 8860 & 3740 & 4280 & 2380 & 1650 \\
\hline
\end{tabular}

${ }^{*}$ days ashore for breeding/moulting are included 


\section{Discussion}

Our study shows that adult female and first year elephant seals from King George Island used different foraging areas, and that the juveniles avoided the sea ice while the adult females did not.

\section{Movements of juveniles}

During their first trip to sea, the five juvenile elephant seals all travelled in a south-westerly direction, even though their movements were more varied than those of the adult females (Figs 3 \& 4). At least four juveniles (one transmitter failed) finally reached the ice-free waters west of the De Gerlache Seamounts where they centred their foraging activities for an extended time period slowing down their movements to one third of the rate of travel (c. $\left.50 \mathrm{~km} \mathrm{day}^{-1}\right)$ from King George Island. In April, the pack ice zone of the Amundsen and Bellingshausen Sea extended to the north. In synchrony with the advancing ice coverage, the juveniles migrated northward and increased their distance from the ice fields. The winter haulout of juvenile elephant seals on the South Shetland Islands accords with observations from elsewhere (Carrick et al. 1962, Hindell \& Burton 1988, Bell et al. 1997). The reasons for this winter haulout are not yet understood but there are no obvious physiological processes related to the time ashore.

Studies on other pinnipeds (Oliver et al. 1998, Ridoux et al. 1998) have shown that even juvenile seals have well-developed navigational skills. How the young elephant seals in our study located their feeding grounds remains unclear but we assume that learning by foraging in addition to genetically-programmed orientation are the most significant factors especially for an inexperienced, first year animal that needs to locate profitable areas in the open ocean. The De Gerlache Seamounts are the most prominent topographic feature of the region. These submarine structures may be responsible for hydrographic features (e.g. local gyres and upwellings) that presumably lead to enhanced food availability with prey densities possibly higher than elsewhere in the deep waters of the open ocean traversed by the juvenile seals. In the absence of hard oceanographic data and biomass data on potential prey resources, further discussion about the question as to why the juveniles used just these oceanic feeding grounds whereas the adult females did not, is speculative.

\section{Foraging ranges of adult females}

Of the nine female elephant seals tracked in our study, three animals $\left(A_{3}\right.$, ) stayed close to the South Shetland Islands while the other six $\left(A_{1}, A_{2}\right)$ were localized in the Bellingshausen Sea as far as $90^{\circ} \mathrm{W}$ (Fig. 4). Their previous breeding site, King George Island, was $1600 \mathrm{~km}$ away from both the southernmost foraging localities in the Bellingshausen Sea and the island of South Georgia. Adult female elephant seals tagged on South
Georgia (McConnell \& Fedak 1996) swim much greater distances, travelling either to the open ocean up to $3000 \mathrm{~km}$ east of South Georgia or to the continental shelf of the Antarctic Peninsula and the Falkland Islands. In our study females Af5 and Afl1 (Fig. $4 a$ \& b) hauled out on South Georgia the following breeding season (probably to pup) and then returned directly to the Peninsula.

Female elephant seals from King George Island and South Georgia showed remarkably similar tracks along the continental shelf edge of the Antarctic Peninsula. Of the four females which travelled from South Georgia directly to the Antarctic Peninsula(McConnell et al. 1992, McConnell \& Fedak 1996), two seals reached their most southerly positions in an area $c$. $100 \mathrm{~km}$ off Adelaide Island. This shelf area coincided with a slow-moving phase by six females $\left(A_{1}, A_{2}\right)$ tracked in our study, although they extended their foraging ranges about $1000 \mathrm{~km}$ further south-west of Adelaide Island moving to the Bellingshausen Sea as far as $90^{\circ} \mathrm{W}$. Even the females Af5 and Af11 which travelled from the Bellingshausen Sea directly to South Georgia, rapidly returned to the Peninsula to forage for several weeks (prior to moulting) in the shelf waters north-east of King George Island (Af11) or south-west of Adelaide Island (Af5). Of the 13 females tagged in our study, eight were again localized on King George Island the following season and of these six (Af1, Af2, Af3, Af4, Af7, Af9) gave birth in October/November and two seals (Af8, Af11) moulted in January/February.

Fedak \& McConnell (1993) argued that the movement away from South Georgia may be explained by the fact that the local shelf area contains insufficient prey to sustain the local breeding population of elephant seals. The west coast of the Antarctic Peninsula belongs to the CCAMLR Subareas 88.3 and 48.1. Except for the Peninsula Subarea 48.1, where commercial krill fishing is carried out by several member nations, commercial catches of fish have been prohibited since 1989 by CCAMLR in both subareas (K.-H. Kock, personal communication 1999). Additionally, fish biomass values from the Peninsula region are reported to be about ten to fifteen times higher than in high latitude shelf waters of the Weddell Sea (Ekau 1990). The west coast of the Antarctic Peninsula coast may therefore represent attractive foraging sites where elephant seals from King George Island and South Georgia benefit from commercially unexploited food resources.

The proximity of potential feeding areas to King George Island may result in an energetic advantage for animals which breed there compared with those that breed at South Georgia. This may explain why females arriving at King George Island are heavier and wean heavier pups than at other breeding sites (Burton et al. 1997, Carliniet al. 1997) and why post-breeding animals returning to moult have a greater increase in body mass than South Georgian animals, despite having spent less time at sea (Carlini et al. 1999). In overwintering in one area and having to breed and moult in another, elephant seals could be loosely regarded as central place foragers (sensu Orians \& Pearson 1979). According to central place foraging theory 
(Orians \& Pearson 1979) success depends on factors which include the distance the animal has to travel, with associated costs, the rate at which energy can be accumulated and the time which has to be devoted to the two phases. Based on this, it would appear in our study that the elephant seal foraging localities in the Bellingshausen Sea are the most lucrative, this locality being farthest from the breeding site. It might also be that only the animals from King George Island can exploit these regions, the travel costs being too high to be viable for the animals from South Georgia.

\section{Use of the sea ice habitat}

The sea ice extent and timing of breakout has been assumed to influence the colony build-up at the breeding or moulting sites of southern elephant seals (Laws 1956, 1960, Tierney 1977, Burton 1985, Gales \& Burton 1989) but almost nothing is known about how sea ice conditions might influence foraging at sea. The overall travel pattern of the nine adult females in our study revealed a clear preference for foraging in the coastal shelf waters of the Antarctic Peninsula. At least females Af1, Af2, Af5, Af8 and Af1 1, which had transmitters operating after May (Table I), spent most of the winter in the floating sea ice zone but at different times and localities. In particular, four females $\left(A_{2}, A_{3}\right)$ never moved into the pack ice, but adjusted their foraging patterns to the seasonally pulsating sea ice fringe. In contrast, the other five females $\left(A_{1}\right)$ ranged for several months in heavy pack ice.

During the entire tracking period of 15 months, the shelf region west of the Antarctic Peninsula was influenced by large changes in the seasonally advancing and receding sea ice coverage, as demonstrated in Fig. 2. Such pronounced variations in sea ice concentration and extent, and thus in the location of the ice edge, will effect the seasonal distribution patterns of top predators and their prey. Various studies have confirmed that the retreating marginal sea ice zone is highly productive (e.g. Smith \& Nelson 1985, Ainley \& DeMaster 1990) and attracts many predators such as seabirds (e.g. Ainley \& Jacobs 1981, Hunt \& Veit 1983, Ainley et al. 1998), and ice-associated pinnipeds. For instance, Siniff et al. (1970) found greatest summer concentrations of crabeater seals at the periphery of heavy pack ice with increasing ice density corresponding to decreases in crabeater abundance. The authors considered chlorophyll $a$ concentration and the depth of the euphotic zone the most important factors to influence the distribution of seals. Because of restricted ship access, relatively little is known about the distribution of top predators during winter, particularly in the central parts of pack ice regions. In the interior pack over the Weddell Abyssal Plain, crabeater seals, minke whales, Adélie penguins and other seabirds were found to be more abundant than in other regions of substantial ice cover traversed during a mid-winter cruise (Plötz et al. 1991). These authors reported that the distribution of krill predators was remarkably patchy and coincided with the course of a warm water belt upwelling near a submarine seamount (Maud Rise) where abundant krill was found wintering beneath the ice.

Recent studies using satellite telemetry have provided a more detailed picture of the seasonal migratory patterns of seals in the pack ice zone. Nordøy et al. (1995) found that crabeater seals followed the extending ice to the north of the Weddell Sea in late summer but returned to deeper pack in winter. Crabeaters satellite-tagged at the Antarctic Peninsula coast in February/March (Bengtson et al. 1993) tended to stay in the same general region, up to July when transmissions ended, and even returned to areas occupied in earlier months, i.e. either to the Bransfield Strait or west of Alexander Island. It is of particular interest that precisely these shelf areas were also used by adult female elephant seals in our study and in those of McConnell et al. (1992) and McConnell \& Fedak (1996).

\section{Food web implications}

A unique key position in the neritic food webs of the Southern Ocean is occupied by the planktivorous Pleuragramma antarcticum Boulenger, being considered the most abundant fish in the Ross Sea (e.g. DeWitt 1970), Weddell Sea (e.g. Hubold 1984) and around the Antarctic Peninsula(Kellermann 1987). The ubiquitous occurrence and importance of Pleuragramma in the high Antarctic food webs is emphasized by the fact that this species represents the predominant food item for Weddell seals in both the Ross Sea (e.g. Davis et al. 1982, Castellini et al. 1984, Testa et al. 1985) and the Weddell Sea(Plötz 1986). Adult female Weddell seals satellite-tagged in the Ross Sea are reported to utilize the pack ice environment in winter (Testa 1994) and even weaned pups tend to utilize the pack ice habitat from late summer to early winter (Burns et al. 1999). Based on the Weddell seals' diving performances in both winter and summer, Testa (1994) suggests a continued reliance on Pleuragramma as their principal prey, though other fish and cephalopods cannot be excluded. Kellermann (1986), in his study on post-larval distribution patterns of Pleuragramma off the Antarctic Peninsula, concluded that the seasonal pack ice zone of the Bransfield Strait and adjacent waters represent nursery grounds for the early stages and are probably only used as a temporary habitat before the mature fish migrate to their spawning grounds in the permanent pack ice zone of the Bellingshausen Sea and north-western Weddell Sea. DeWitt \& Hureau (1979) recorded adult Pleuragramma near Adelaide Island, and Daniels (1982) reported the species to be common from south of Adelaide Island to the Palmer Archipelago (i.e. Alexander Island included) where schools of several thousands have been observed under fast ice.

We have identified from our data and those presented in literature (McConnell et al. 1992, McConnell \& Fedak 1996) two principal regions along the coast of the Antarctic Peninsula where adult female elephant seals repeatedly centre their foraging activity for extended time periods. These regions are the Bransfield Strait and adjacent waters, and the entire shelf 
of the Bellingshausen Sea west of Adelaide and Alexander Island up to $90^{\circ} \mathrm{W}$.

In this study we show that the foraging habitats of female elephant seals are closely associated with the sea ice zone. Fedak et al. (1994) interpreted the diving activity of one female elephant seal, that remained in a small area west off Adelaide Island, as demersal or benthic feeding, probably on cephalopods. In this context the authors point out that, if feeding areas are far away from the breeding sites (in that case South Georgia), stomach samples taken elsewhere on land with remains of squids or octopods may under-represent the consumption of fish whose remains are retained in the stomach for shorter periods. We strongly support this argument and, although cephalopods can not be excluded, there is little reason to doubt that the pack ice habitat at the west coast of the Antarctic Peninsula represents attractive foraging sites where elephant seals benefit from the availability of Pleuragramma.

\section{Acknowledgements}

The seal studies were part of the German-Argentinean cooperative project at the Dallmann-Laboratory, Jubany Station, King George Island, Antarctica. We wish to thank our Argentinean colleagues for the good collaboration. We are grateful to S. Poljak, R. Conde, R. Montiel, and M. Alcalde, who provided their expertise in elephant seal research and supported the field work. The Argentinean field team of the $1997 / 98$ season kindly recovered the satellite transmitters at the colony "Stranger Point" on King George Island. Thanks are due to J. Bengtson, and R. Hill who trained us in using the satellite-linked dive recorders. We are grateful to M. Hindell, B. McConnell and R. Wilson for useful comments which improved the manuscript. Data of ice concentration for 1996/ 97 are provided by the EOS Distributed Archive Center (DAAC) at the National Snow and Ice Data Center (NSIDC), University of Colorado, Boulder, CO, USA. The 1998 data are calculated by using data of the Global Hydrology Resource Center (GRHC), Global Hydrology and Climate Center, Huntsville, AL, USA. Maps have been generated by using the plot-software of GMT.

This is publication No 1596 of the Alfred-Wegener-Institut für Polar- und Meeresforschung, Bremerhaven, Germany.

\section{References}

AINLEY, D.G. \& JACOBS, S.S. 1981. Seabird affinities for ocean and ice boundaries in the Antarctic. Deep-Sea Research, 28A, 1173-1185.

AinLEY, D.G. \& DeMaster, D.P. 1990. Upper trophic levels in polar marine ecosystems. In SMITH JR, W.O., ed. Polar Oceanography Part B Chemistry, biology and geology. San Diego, CA: Academic Press, 599-630.

Ainley, D.G., Jacobs, S.J., Ribic, C.A. \& Gaffney, I. 1998. Seabird distribution and oceanic features of the Amundsen and southern Bellingshausen seas. Antarctic Science, 10, 111-123.

ARGOS 1996. CLS ARGOS user manual 1.0, chapter 2.3.5, 27.
Bengtson, J.L. 1993. Telemetry and electronic technology. In Laws, R.M., ed. Antarctic seals, research methods and techniques Cambridge: Cambridge University Press, 119-139

Bengtson, J.L., Hill, R.D. \& Hill, S.E. 1993. Using satellite telemetry to study the ecology and behavior of Antarctic seals. Korean Journal of Polar Research, 4, 109-115.

Bell, C.M., Burton, H.R. \& Hindell, M.A. 1997. Growth of southern elephant seals, Mirounga leonina, during their first foraging trip. Australian Journal of Zoology, 45, 447-358.

Bester, M.N. \& Pansegrouw, H.M. 1992. Ranging behaviour of southern elephant seal cows from Marion Island. South African Journal of Science, 88, 574-575.

BoYD, I.L. \& ARNBOM, T. 1991. Diving behaviour in relation to water temperature in the southern elephant seal: foraging implications. Polar Biology, 11, 259-266.

Burns, J.M., Castellini M.A. \& Testa, J.W, 1999. Movements and diving behaviour of weaned Weddell seal (Leptonychotes weddellii) pups. Polar Biology, 21, 23-36.

BURTON, H.R. 1985. Tagging studies of male southern elephant seals (Mirounga leonina L.) in the Vestfold Hills area, Antarctica, and some aspects of their behaviour. In LING, J.K. \& BRYDEN, M.M., eds. Sea mammals in south latitudes. Proceedings of a symposium of the 52nd ANZAAS Congress in Sydney - May 1982 Adelaide: South Australian Museum, 19-30.

Burton, H.R., Arnbom, T., Boyd, I.L., Bester, N., Vergani, D. \& WILKINSON, I. 1997. Significant differences in weaning mass of southern elephant seals from five sub-Antarctic islands in relation to population declines. In Battaglia, B., Valencia, J. \& Walton, D.W.H., eds. Antarctic communities: species, structure and survival Cambridge: Cambridge University Press, 335-338.

Carlini, A.R., Daneri, G.A., Marquez, M.E.I., Soave, G.E. \& Poljak, S. 1997. Mass transfer from mother to pups and mass recovery by mothers during the post-breeding foraging period in southern elephant seals (Mirounga leonina) at King George Island. Polar Biology, 18, 305-310.

Carlini, A.R., Marquez, M.E.I., Daneri, G.A. \& Poljak, S. 1999. Mass changes during their annual cycle in females of southern elephant seals at King George Island. Polar Biology, 21, 234-239.

Carrick, R., Csordas, S.E., Ungham, S.E. \& Keith, K. 1962. Studies on the southern elephant seal Mirounga leonina (L.) III. The annual cycle in relation to age and sex. CSIRO Wildlife Research, 7, 119-160.

Castellini, M.A., Davis, R.W., Davis, M. \& Horning, M. 1984. Antarctic marine life under the McMurdo Ice Shelf at White Island: a link between nutrient influx and seal population. Polar Biology, 2, 229-231.

Cavalieri, D.J., Gloersen, P. \& Campbell, W.J. 1984. Determination of sea ice parameters with the Nimbus 7 SSMR. Journal of Geophysical Research, 89(D4), 5355-5369.

Comiso, J.C., Cavalieri, D.J., Parkinson, C.L. \& Gloersen, P. 1997. Passive microwave algorithm for sea ice concentration: a comparison of two techniques. Remote Sensing of Environment 60, 357-384.

Daniels, R.A. 1982. Feeding ecology of some fishes in the Antarctic Peninsula. Fishery Bulletin, 80, 575-588.

Davis, R.W., Castellini, M.A., Horning, M., Davis, M.\& Kooyman, G. 1982. Winter ecology of Weddell seals at White Island. Antarctic Journal of the United States, 17(5), 183-184.

DeWitT, H.H. 1970. The character of the midwater fish fauna of the Ross Sea, Antarctica. In Holdgate, M.W., ed. Antarctic ecology, vol.1. London: Academic Press, 305-314.

DeWitt, H.H. \& Hureau, J.C. 1979. Fishes collected during Hero cruise 72-2 in the Palmer Archipelago, Antarctica, with the description of two new genera and three new species. Bullentin du Muséum National d'Histoire Naturelle, Seriés 4A, 3, 775-820. 
EkaU, W. 1990. Demersal fish fauna of the Weddell Sea, Antarctica. Antarctic Science, 2, 129-137.

FedAK, M.A. \& McConnell, B.J. 1993. Observing seals by satellite. In Jones, L., ed. NERC News April 1993, 29-28.

Fedak, M.A., Arnbom, T.A., McConnell, B.J., Chambers, C., Boyd I.L., HarwoOd, J. \& MCCANN, T.S. 1994. Expenditure, investment, and acquisition of energy in southern elephant seals. In LE BOEUF, B.J. \& Laws, R.M., eds. Elephant seals: population ecology, behavior, and physiology. Berkeley: University of California Press, 354-373.

Gales, H.R. \& BURTon, N.J. 1989. The past and present status of the southern elephant seal Mirounga leonina (L.) in greater Antarctica. Mammalia, 53, 35-47.

Hindell, M.A.\& Burton, H.R. 1988. Seasonal haulout patterns of the southern elephant seal (Mirounga leonina) at Macquarie Island. Journal of Mammalogy, 69, 81-88.

Hindell, M.A., Burton, H.R. \& Slip, D.J. 1991a. Foraging areas of southern elephant seals, Mirounga leonina as inferred from water temperature data. Australian Journal of Marine and Freshwater Research 42, 115-128.

Hindell, M.A., SLIP, D.J. \& Burton, H.R. 1991b. The diving behaviour of adult male and female southern elephant seals, Mirounga leonina (Pinnipedia: Phocidae). Australian Journal of Zoology, 39, 595-619.

Hubold, G. 1984. Spatial distribution of Pleuragramma antarcticum (Pices: Nototheniidae) near the Filchner and Larsen ice shelves (Weddell Sea/Antarctica). Polar Biology, 3, 231-236.

Hunt JR, G.L. \& VeIT, R.R. 1983. Marine bird distribution in Antarctic waters. Antarctic Journal of the United States, 18(5), 167-169.

JONKER, F.C. \& BESTER, M.N. 1998. Seasonal movements and foraging areas of adult southern female elephant seals, Mirounga leonina, from Marion Island. Antarctic Science, 10, 21-30.

KellermanN, A. 1986. Geographical distribution an abundance of postlarval and juvenile Pleuragramma antarcticum (Pisces, Notothenioidei) off the Antarctic Peninsula. Polar Biology, 6, 111-119.

KellermanN, A. 1987. Food and feeding ecology of postlarval and juvenile Pleuragramma antarcticum (Pisces: Notothenioidei) in the seasonal pack ice zone off the Antarctic Peninsula. Polar Biology, $7,307-315$

KING, J.E. 1983. Southern elephant seal (Mirounga leonina). In King, J.E. Seals of the world, 2nd ed. London: British Museum (Natural History), 119-124.

LAws, R.M. 1956. The elephant seal (Mirounga leoninaL.) II. General, social and reproductive behaviour. Falkland Islands Dependencies Survey Scientific Reports, No. 13, 1-88.

Laws, R.M. 1960. The southern elephant seal (Mirounga leonina Linn.) at South Georgia. Norsk Hvalfangst-tidende, 49, 466-476 and $11,520-542$.

Laws, R.M. 1984. Seals. In Laws, R.M., ed. Antarctic ecology, vol. 2. London: Academic Press, 621-715.

McConnell, B.J., Chambers, C. \& Fedak, M.A. 1992. Foraging ecology of southern elephant seals in relation to bathymetry and productivity of the Southern Ocean. Antarctic Science, 4, 393-398.
McConnell, B.J. \& Fedak, M.A. 1996, Movements of southern elephant seals. Canadian Journal of Zoology 74, 1485-1496.

MURRAY, M.D. 1981. The breeding of the southern elephant seal, Mirounga leonina L., on the Antarctic continent. Polar Record, 20 , 370-371.

Nordøy, E.S., Folkow, L. \& SchytTe Blix, A. 1995. Distribution and diving behaviour of crabeater seals (Lobodon carcinophagus) off Queen Maude Land. Polar Biology, 15, 261-268.

Oliver, G.W., Morris, P.A., Thorson, P.H. \& Le Boeuf, B. 1998. Homing behaviour of juvenile northern elephant seals. Marine Mammal Science, 14, 245-256.

OrIans, G.H. \& Pearson, N.E. 1979. On the theory of central place foraging. In HoRn, D.J., Mitchell, R. \& STAIR, G.R., eds. Analysis of ecological systems. Columbus, $\mathrm{OH}$ : Ohio State University Press, $155-177$.

PLÓTZ, J. 1986. Summer diet of Weddell seals (Leptonychotes weddellii) in the eastern and southern Weddell Sea, Antarctica. Polar Biology, 6, 97-102.

Plotz, J., Weidel, H. \& Bersch, M. 1991. Winter aggregations of marine mammals and birds in the north-eastern Weddell Sea pack ice. Polar Biology, 11, 305-309.

PRIEDE, I.G. \& FrenCH, J. 1991. Tracking of marine animals by satellite. International Journal of Remote Sensing 12, 667-680.

Ridoux, V., Hall, A.J., Steingrimsson, G. \& Olafsson, G. 1998. An inadvertent homing experiment with a young ringed seal, Phoca hispida. Marine Mammal Science, 14, 883-894.

Siniff, D.B., Cline, D.R. \& Erickson, A.W. 1970. Population densities of seals in the Weddell Sea, Antarctica, in 1968. In Holdgate, M.W., ed. Antarctic ecology, vol. 1. London: Academic Press, 377-394.

SLIP, D.J. 1997. Diving and foraging behaviour of juvenile southern elephant seals from Heard Island. In HiNDELL, M. \& KEMPER, C., eds. Marine mammal research in the southern hemisphere, 1. Status, ecology and medicine. Chipping Norton, Australia: Surrey Beatty \& Sons, 114-124.

Slip, D.J., Hindell, M.A. \& Burton, H.R. 1994. Diving behaviour of southern elephant seals from Macquarie Island: an overview. InLE BoEUF, B.J. \& LAWS, R.M., eds. Elephant seals: population ecology, behavior, and physiology. Berkeley: University of California Press, 253-270.

SMIth, W.O. \& Nelson, D.M. 1985. Phytoplancton bloom produced by a receding ice edge in the Ross Sea: spatial coherence with the density field. Science, 227, 163-166.

TEsTA, J.W. 1994. Over-winter movements and diving behaviour of female Weddell seals (Leptonychotes weddellit) in the south-western Ross Sea, Antarctica. Canadian Journal of Zoology 72, 1700-1710.

Test A, J.W., Siniff, D.B., Ross, M.J. \& Winter, J.D. 1985. Weddell seal-Antarctic cod interactions in McMurdo Sound, Antarctica. In Stegrried, W.R., Condy, P.R. \& Laws, R.M., eds. Antarctic nutrient cycles and food webs. Berlin: Springer Verlag, 561-565.

TIERNEY, T.J. 1977. The southern elephant seal, Mirounga leonina (L.), in the Vestfold Hills, Antarctica. Australian Journal of Wildlife Research, 4, 13-24. 